\title{
MANIFESTATION OF MODERNITY IN IRANIAN PUBLIC SQUARES: BAHARESTAN SQUARE (1826-1978)
}

\author{
ASMA MEHAN \\ Department of Architecture and Design, Politecnico Di Torino, Italy.
}

\begin{abstract}
The concept of public square has changed significantly in Iran in recent centuries. This research investigated how modernity is manifested in the public squares of Tehran. In this regard, Tehran has been chosen as the main concern, while in its short history as the capital of Iran, the city has been critically transformed: first because of constant urban development during the Qajar Dynasty and then due to its rapid growth during the late Pahavi era and second because of the culture of rapid renovation and reconstruction in contemporary public spaces. Considering these facts, the urban transformation of Baharestan Square as one of the most influencing public squares of Tehran in the recent century leads us to understand the process of Iranian modernization, which is totally different from common patterns of western modernity. Analysing the historical changes of Baharestan Square based on manuscripts, western travellers' diaries, historical images and maps, from its formation till the Islamic Revolution (1978), shows how the traditional elements of the square as well as its form and function have been totally transformed. Analysing the spatial qualities of Baharestan Square clarifies that its special location near the first Iranian Parliament building, Sepahsalar Mosque and Negarestan Garden represents it as the first modern focal point in Iranian's political and social life.
\end{abstract}

Keywords: Baharestan Square, Iranian modernity, public square, Tehran.

\section{INTRODUCTION}

Public squares are significant parts of the history and the culture of the cities. The squares reveal the life and the historical identity of the cities, while they are scenes of urban transformations. In Iranian history, squares were important places for improving social interactions of citizens and enhancing the quality of urban lives. Traditionally, squares served multipurpose functions. They were activity zones for all kinds of events, from public gatherings to daily markets and public celebrations [1,2]. The traditional patterns of use for public squares were in place till the modern ages when the kings started to travel to Europe and import the European patterns of city planning and mix them with the traditional layout of the cities. Those new patterns created squares with new functions around them, such as cinema, theatre, bank, hotel, university, etc., while on the other hand the entry of automobiles had an effective influence on the form and size and number of squares. As a result, squares which were once the most important node for daily activities of the inhabitants of the cities started to be replaced by new functions as well as new form and lose its vital and active role in the minds of the inhabitants of the cities [3]. In the traditional Persian squares, the same pattern of design of courtyard houses and mosques was followed; they were oriented around a central pool that was an aesthetic centre as well as a practical feature for the people who used them. New squares, as the new centres of urban activity, were for the first time filled with figurative sculptures, as evidence of departure from the past and of Islam's disapproval of public representation of figures [4]. During the 20th century, the urban squares of Tehran and the large cities, such as Baharestan Square in front of the national parliament, have frequently

This paper is part of the Proceedings of the International Conference on Islamic Heritage Architecture and Art (Islamic Heritage Architecture 2016)

www.witconferences.com 
been spaces of political contest. While the kings used them to display their power, the revolutionary masses used them as their meeting points and places to challenge the authorities; in this sense, there was a close link between the social movements and the public spaces of the city [5]. Considering these facts, reviewing the urban transformation of Baharestan Square shows how the traditional elements of the square as well as its form and function have been totally transformed.

\section{HISTORY OF IRANIAN PUBLIC SQUARES}

The word Meidan has pre-Islamic roots in mai-ta-ni (hippodrome), and in the case of Persian cities, it has been observed that each city had at least one central square, used for trade and public gatherings [4]. Public square has a long history and special place in the history of Iranian urbanism and dates back to before Islam. History of Iranian public square dated back to 9 B.C to 3 A.C, which was a multifunctional centre for cultural, official and commercial purposes. It functioned as an official-political space and acted as a place for power of Soluki government [6]. The meaning of square in Iran as the centre of cultural, economical and official exchanges has mostly been derived from the city planning of the Seleucid Empire in 312-63 B.C. [7]. The axial geometrical pattern of Iranian cities, with walls surrounding them and their square-shaped form and internal axial layout, specifically in eastern Iran, developed from the middle of the first millennium BC. However, this pattern of Parthian and Sassanid cities did not change, despite Muslims' attempts after the conquest of the country in 7th century, and the symbolic, pre-Islamic significance of Persian cities continued until the 19th century. Even in 19th-century Tehran, which was a city mostly built on western visions, the axiality of urban form worked alongside public squares [8]. In a general analysis of the history of square in Iranian cities, it can be observed that, traditional Iranian cities have at least one large public square located either near the city gates or at the centre of the cities, and smaller squares that form the centres of residential neighbourhoods which were specifically used as gathering places during important religious, political and socio-cultural events, such as rituals of Muharram and Ramadan, elections and executions, and the celebration of Persian holidays, such as Nourooz; in ordinary days of the year the squares were used by retailers for trading purpose $[1,2]$. Table 1 presents the transition history of Iranian public squares.

Table 1: Transition history of Iranian public squares.

\begin{tabular}{|c|c|c|c|}
\hline \multirow{3}{*}{ 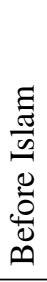 } & Era & Time period & Functions \\
\hline & $\begin{array}{l}\text { Soluki Dynasty } \\
\text { (Persian-Hellenic } \\
\text { city) }\end{array}$ & $\begin{array}{l}9 \text { B.C. to } 3 \\
\text { A.C. }\end{array}$ & $\begin{array}{l}\text { Place for economical trades like Greek Agora; } \\
\text { multifunctional centre for cultural, official and } \\
\text { commercial purposes }\end{array}$ \\
\hline & $\begin{array}{l}\text { Sassanid Dynasty } \\
\text { (Shahr-E-Parti) }\end{array}$ & $\begin{array}{l}3 \text { A.C. to } 7 \\
\text { A.C. }\end{array}$ & $\begin{array}{l}\text { Manifestation of power in the government like } \\
\text { Roman Forum }\end{array}$ \\
\hline \multirow{3}{*}{$\frac{\Xi}{\frac{\Xi}{\omega}}$} & $\begin{array}{l}\text { Safavid era (Isfahani } \\
\text { style) }\end{array}$ & 1501-1785 & $\begin{array}{l}\text { Public square surrounded by various urban } \\
\text { spaces such as governmental buildings, great } \\
\text { mosque, bazaar, religious school and public bath }\end{array}$ \\
\hline & $\begin{array}{l}\text { Qajar Dynasty (Teh- } \\
\text { rani style) }\end{array}$ & 1785-1921 & $\begin{array}{l}\text { Bazaar and square were still the backbone } \\
\text { of the city, and other public spaces were its } \\
\text { inseparable spaces }\end{array}$ \\
\hline & $\begin{array}{l}\text { Pahlavi era (Indus- } \\
\text { trial Revolution } \\
\text { period) }\end{array}$ & 1921-1978 & $\begin{array}{l}\text { Inspired by western urbanism and architectural } \\
\text { style, continuity in form, advent of automobiles, } \\
\text { paying attention to details in façade of squares }\end{array}$ \\
\hline
\end{tabular}

Source: The author. 
Alongside being a node of gathering and a place of contest of the society, public squares held the spatial representation of the power pillars of the society. The modern squares in the urban 20th century were just traffic nodes for transportation. Therefore, public squares transformed to an unknown territory in which people pass their time without any enthusiasm. Some of the old squares with a rich history and imposing monuments became traffic intersections or boring parking lots [12].

\section{TEHRAN PUBLIC SQUARES AND MODERNIZATION PROCESS}

Tehran is a walled city with twelve gates, built of mud brick, which were meant to control the entering and exiting of people and objects from the city, and was expanded around a covered bazaar and a mosque. The capital city, built in the Islamic pattern in the early 20th century, consisted of four main structural elements: wall and gates, royal citadel, religious structures and residential quarters. The public spaces of the time were mostly the religious structures of the city; and Arg, Bazaar and Masjed-e Shah were the three elements of the power and sources of authority [9]. Tehran is a 200-year-old capital and most of its primary squares were built during the modern period.

The oldest square of Tehran dates to 1540, when the king ordered to surround the city with walls, and the inhabitants could build their homes on the ground; before that because of security problems, people of Tehran used to build their homes under ground level. It is believed that the oldest square of Tehran was in a region called 'Chal Meidan', and the square was at the place of the mosque of that district [10]. In the process of modernization, most of the squares bear little resemblance to their earlier counterparts. The new squares were neither naturally evolved spaces of tradition nor primarily open-ended centres of activity for people. They were symbols of axial planning in the Western sense, visual nodes and keys to the city's image. Within the urban grid, they formed expansive traffic circles and became Le Corbusier's 'apparatus for circulation'. These large and symmetrical public squares and circles were planned for the intersections of streets and were intended as grand, monumental focal points of the city. While earlier squares were like medieval open spaces that were evolving in time and covering variety of pubic activities, modern squares were static places dedicated to symbolism rather than activism [4]. Some of the most important characteristics of public squares in this era are as follows: paying attention to physical aspects of square façades, inspiring from western urbanism and architecture style, continuity in form, advent of automobiles in urban spaces, locating at the intersections of main streets, regular geometric shape especially rectangular and circular form and paying attention to details in façade of squares [11]. Therefore, public squares transformed to an unknown territory in which people pass their time without any enthusiasm. Some of the old squares with rich history and imposing monuments became traffic intersections or boring parking lots [12]. For better analysis, some primary squares of Tehran from Safavid era to Pahlavi era during the modernization time have been analysed in Table 2 .

Table 2: General characteristics of primary built squares in Tehran [13].

\begin{tabular}{lll}
\hline Historical era & General characteristics & Tehran's built squares \\
\hline Safavid Dynasty (till 1869) & Enclosed, introvert, compact & Sabzeh-Maydan \\
& without order, narrow & Arg Maydan \\
Qajar Dynasty (1869-1925) & $\begin{array}{l}\text { Geometrical shape, vast scale, } \\
\text { enriching perspective }\end{array}$ & $\begin{array}{l}\text { Top-Khane Maydan } \\
\text { Baharestan Maydan }\end{array}$ \\
\hline
\end{tabular}


Table 2 (Continued)

\begin{tabular}{lll}
\hline & $\begin{array}{l}\text { Extrovert, homogeneous urban } \\
\text { edges, use of glass, metal and } \\
\text { Pahlavi I (1925-1933) } \\
\text { of main streets }\end{array}$ & $\begin{array}{l}\text { Mokhber-Al-Doleh } \\
\text { Rah-Ahan Maydan } \\
\text { Hasan-Abad Maydan }\end{array}$ \\
\hline
\end{tabular}

\section{MODERNIZATION OF TEHRAN}

Tehran, the capital of Iran, has experienced different styles of modernization during the last five decades. There were two revolutions in the last century that dramatically influenced the conditions of modernity in Tehran; the constitutional revolution (1905-1907) at the beginning of 20th century opened the doors to modern and particularly western school of thoughts and life styles. On the other hand, Islamic Revolution (1978-1979) challenged everything associated with the West and its modernity in relation to the Islamic identity [21].

Since the Qajar Dynasty (1785-1925), Iranian architecture has confronted Western ideological concepts [14]. Upon the demise of the Qajar, both Reza Shah (1925-1941) and his son and successor king, Mohammad Reza Shah (1941-1979), forcefully modernized the society that had been rooted in pre-Islamic past, Islam and metaphysical ideology. Such radical changes were employed in all aspects of everyday life of the society, from ideological to physical transformations [8]. The modernization project in Tehran as the result of the global economy, similar to some other cities such as Cairo and Istanbul, was associated with several changes to the socio-spatial structure of the city [15]. These include deterioration of the city's historical core; emergence of wide streets, squares, parks and buildings in a semi-European style; and fast expansion of the city to accommodate migration from the provinces to the capital and formation of informal settlements, overpopulation and rise of new social classes such as bureaucrats and middle class state employees $[8,16]$. The process of modernization of Tehran started slowly during the Qajar Dynasty and was more rapid and autocratic during the Pahlavi Dynasty that imposed modern and western ideas and technologies both on the city form and everyday practices, to re-image the capital city and appropriate it for the world market [17]. The following time periods trace the three different stages of Tehran modernization: 1870-1921, 1925-1940 and 1941-1978.

\subsection{First stage (from 1870 to 1921 )}

The medieval city of Tehran, as prototypical for most of Iranian Islamic cities, was made of three major elements: the bazaar, the citadel and the residential neighbourhoods [15]. The outcome of the Qajari kings' visit to Europe was the expansion and redevelopment of Tehran by introducing a new city centre on the old urban fabric; the destruction and replacement of the organic walls with hexagonal ones designed by General Buhler (1872) inspired by French medieval cities provided vacant lands for future developments. A new centre that included modern institutions such as banks, hotels, theatres, embassies, wide streets, shops, parks and a modern school in a semi-European style was created at the northern part of the city in the late 19th century and early 20 th century $[8,18,19]$. The introduction of modern ideas was not only limited to urban form but also included political, educational and institutional organizations. In addition, after the Constitutional Revolution of 1907, the first national parliament was established which marked the point of entry into the realm of modernity in Iran's 
history [8, 20]. During the Qajar Dynasty (1794-1925), despite the stereotype of public spaces in the Middle East, the use of public spaces also started to change; the new wide and straight semi-European streets facilitated the use of wheeled carriage, trams and cars [17].

\subsection{Second stage (from 1925 to 1940)}

With the reign of Reza Shah (1925-1940), a new period of modernization started in Tehran. The former walls were demolished again in 1937 to give way to a network of open spaces inspired by Haussmann's project in Paris, including wide streets and circular squares to facilitate the movement of goods, troops and vehicles [15]. New administrative, office, and industrial functions moved to the city centre and accommodated a new image of the city, a modern Tehran. The emergence of modern buildings and boulevards designed by European or European-trained architects resulted in freestanding 'pavilion' buildings in landscape settings [21]. The new state attempted to create a strong national identity through constructing monuments and buildings inspired by international style modernism or Archimedean and pre-Islamic architecture elements and by ignoring and decay of old city centre urban features as the symbol of weakness and backwardness in Iranian history [17]. However, the new model of transport such as cars changed the functions of the public spaces into channels of vehicular movement [8].

\subsection{Third stage (from 1941 to 1978)}

Urbanization during the second Pahlavi can be divided into two stages: The first stage from 1941 to 1961 had a slower pace, while the second stage from oil boom until the 1979 revolution had a faster pace inspired by an American-style urbanization [16]. Bayat [22] states 'Tehran became a site of ever-increasing consumption, as new spending patterns and western lifestyles were adopted; restaurants, Cafes, and inclusive uptown neighborhood appeared. The Shah's regime sought to reshape Tehran into a decentered LA-type suburban entity.' The 1966 comprehensive plan for Tehran, prepared by Victor Gruen, known as American mallmaker, and Farman Farmaian, a master Persian architect, proposed a linear development of Tehran with ten satellite towns mostly along an east-west axis [23]. Mirgholami [15] argues, 'If the previous planning scheme in 1930 was inspired by Paris of Haussmann, the CPT seems to be a reflection of British planning movements like new towns and a linear form of Ebenzer Howard's Garden City Concept.'

\section{BAHARESTAN SQUARE}

The concept of urban space in Iran has a fundamental change during the past 200 years. Baharestan Square, as an important example of the politically loaded squares of Tehran, located in front of the parliament building, has witnessed numerous political meetings, demonstrations, political, national and religious celebrations and clashes [24]. In describing the importance of this political historical square, it has been stated that, Baharestan Square means the square of riot, conflict, revolution and slaughter [25]. Important political events, having a decisive role on the modern history of Tehran, had taken place in Baharestan Square, and as the square was the direct representation and the showcase of the ruling power, the central element and the statue of the centre of the square changed several times, representing the constant changes in the modern history of the city, with its active and ever-changing 
atmosphere [3]. Analysing the spatial and physical changes of Baharestan Square based on manuscripts, western travellers' diaries, historical images and maps, from its formation time in Qajar period (1826) outside of the city till the Islamic Revolution (1978), the traditional elements of the square and its form and function have been totally transformed. For better analysis of the square, physical, functional and spatial characteristics of historical square will be studied in five chronological categories:

\subsection{Forecourt of Negarestan Garden (from 1826 to 1896)}

Negarestan octagonal garden was built in 1807 by Fath-Ali Shah Qajar as one of the summer places of the Qajar Dynasty outside Tehran. Baharestan Square was initially an open space in front of Negarestan garden, which was located outside of the city. Negarestan garden is one of the three illustrated suburban gardens in Nascov's map (1826), which is one of the oldest maps of Tehran from Fath-Ali Shah Qajar period [26]. Gradually, with the development of gardens around Tehran during Qajar era, forecourt of Negarestan was surrounded by Sardar garden, Nezamieh garden and Negarestan garden from three sides. Karla Serena, writer and traveller, who visited Iran around 1877, stated that in those days the square was full of plane and poplar trees [27]. With the development of Tehran in 1868, Negarestan garden became part of the city. With this reposition, Negarestan garden lost its original significance as a recreational garden and was converted into court and government offices [28]. During Qajar era, most of the surrounding lands were used as gardens and arid lands. Accessibility was thus through a narrow way from the western part of the square [29]. Figure 1 shows forecourt of Baharestan Square in the map of 1870.

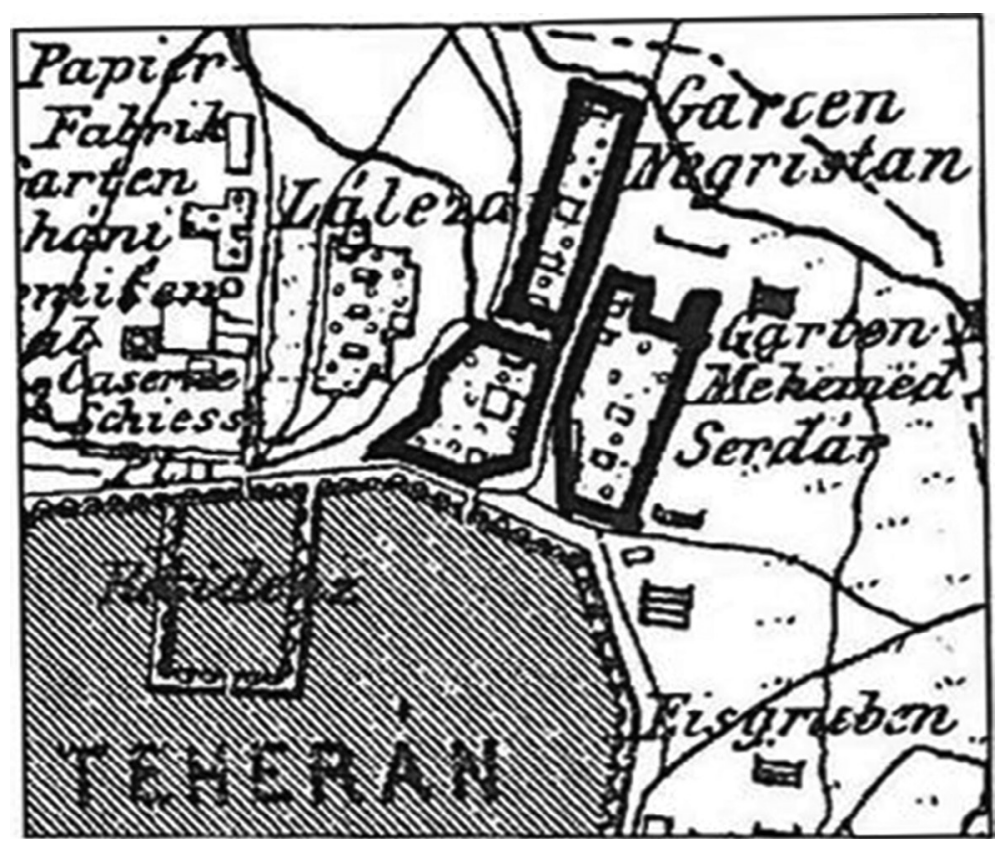

Figure 1: Enlarging the location of Negarestan, Sardar and Nezamieh gardens and forecourt of Baharestan Square, 1870 [2]. 


\subsection{Emergence of political square for urban life (from 1896 to 1925)}

During the reign of Mozaffar ad-Din, Agriculture school, School of Fine Arts (under the supervision of Mohammad Ghaffari, better known as Kamal-ol-Molk, a famous Iranian painter) and Religious School were established in Negarestan garden [30]. In addition, Sepahsalar Mosque became a place for holding important religious events. Transformation in the elements of the square's surrounding and physical location of Baharestan edifice created an appropriate place for establishment of the first Iranian National Parliament in Baharestan Square. However, the square was still called Negarestan Square in official resources and did not have any particular identity [2]. Increasing importance of the square as an urban space led to reconsider its urban details [31]. Baharestan garden in this period was a residence for foreign ambassadors and a place for holding government celebrations. Moreover, after the Persian Constitutional Revolution of 1905-1907, which led to the establishment of Parliament in Baharestan edifice, this historical square became a place for political gatherings and social demonstrations. The 1908 bombardment of the Parliament, political violence and terror of 1907 and social demonstrations of 1924 are some of the major political events that defined another aspect of urban life in Baharestan Square. Reviewing all the political events emphasizes on the determinative role of Sepahsalar Mosque as a focal point for people and constitutionalists. Considering these facts, the recreational function of the square gradually transformed with its surrounding elements and the first political square appeared in Iranian urban spaces. Emergence of modern political institutions like Senate brought new concepts in political literature such as political celebrations, terrors and public demonstrations, which are the fundamental elements of modern life.

\subsection{Autocratic modernization of urban square (from 1925 to 1941)}

In this period, with the expansion of commercial, educational and recreational elements in the square's immediate surroundings, new functions emerged in Baharestan Square. In addition, new network of vehicle transportation converted Baharestan Square into a focal point, which connected the new and old parts of the city. However, after the fire of 1931 and destruction of Parliament building, its large main front porch was renovated in the ancient Iranian style [28]. Shahri [25] argued about introduction of different urban elements for improvement of the public square between 1925 and 1931 such as planting trees, lighting installations, laying pavements, flower designs and separation of footpaths and car roads, like the public European squares in Baroque style. In addition, a statue of Reza Shah was placed in the middle of the square, which was similar to Western public squares. During the Reza Pahlavi era, Baharestan Square was situated in the wealthy part of the city, with the primary cafés in western style, but it was not an active political space like the previous decades.

\subsection{Dual place for people and government (from 1941 to 1955)}

Throughout the 1940s, new buildings were constructed in the northern side of the square in modern style by the Iranian architects who graduated from western universities. Pakdaman [32] argued that projected balconies, new materials, homogeneous white facades in cement, glass stairways in building façade are some of the architectural features of buildings constructed in this era. In these critical years, Baharestan Square was a constant scene of public demonstrations and gatherings to support the nationalization of oil. Moreover, situating the 
offices of political parties, theatres, cafés and bookshops in the square's surrounding emphasized its political, social, recreational and cultural functions [28]. Reviewing the historical events shows that Baharestan Square had a dual position during these years: on the one hand it was a place for manifestation of stability and modernity as part of wealthy neighbourhood of Tehran; on the other hand, it was a main focal point for public and political demands of the people. Figure 2 shows the public demonstrations of 1953 in Baharestan Square.

\subsection{Change in square's urban functions (from 1955 to 1978)}

After the gradual growth of Tehran from the 1950s, the upper classes moved to the north of Tehran. Hourcade [34] argued that after the Royal family selected Niavaran Palace as their place of residence, the town's upper classes left Baharestan neighbourhood to live in the northern parts of the city, which eliminated the previous educational and recreational functions of the square. In the square's surrounding, uniform architectural form shaped that represented the language of early modern architecture. During the 1960s and 1970s, a combination of facades changed into an international architectural style ruined the previous harmony of the square's skyline. In 1955, the square's middle area was a levelled and reconstructed and some new statues were installed as the focal point [35]. However, after the suppression of the 5th of June 1963 uprising and other similar political events, Baharestan Square lost its functional role as a gathering place for the events leading up to the Islamic Revolution of 1978. In addition, ineffectiveness of Iranian Parliament led to political silence in the political life of the square. As a result, the entrance of Tehran University became critical and symbolic nodes of public gatherings in the recent history of this city.

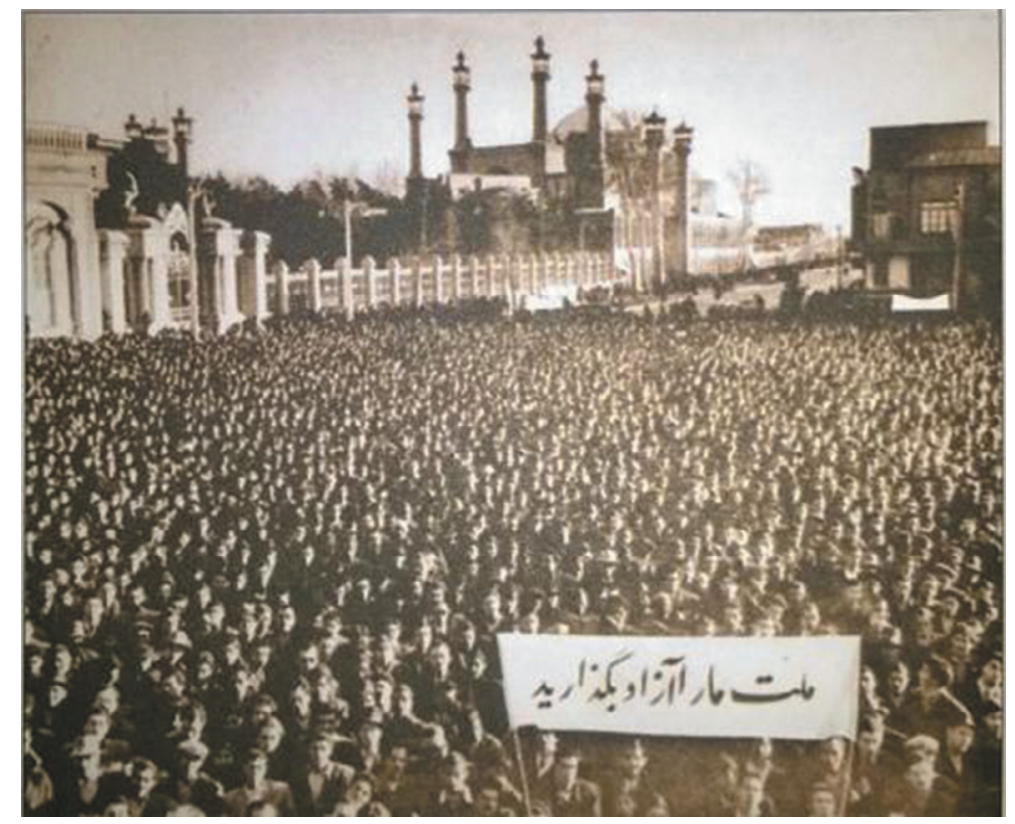

Figure 2: Baharestan Square in demonstrations of 1953 [33]. 


\section{CONCLUSION}

The modernization project in Tehran was dramatically influenced by two revolutions in the last century. The gradual process of Tehran modernization started slowly during the Qajar Dynasty when the kings started to travel to Europe and import the European patterns of city planning and mix them with the traditional layout of the cities and became more rapid and autocratic during the Pahlavi Dynasty, which can be categorized into three different historical periods: 1870-1921 (Late Qajar), 1925-1940 (Pahlavi I) and 1941-1978 (Pahlavi II). However, the spatial, physical and functional transformations of Baharestan Square as one of the most influential public squares of Tehran during the recent century, from its formation during the Qajar period (1826) outside of the city till the Islamic Revolution (1978), shows how modernity manifested gradually in the first Iranian political public square in five chronological stages: forecourt of Negarestan Garden (from 1826 to 1896), emergence of political square for urban life (from 1896 to 1925), autocratic modernization of urban square (from 1925 to 1941), dual place for people and government (from 1941 to 1955) and change in square's urban functions (from 1955 to 1978). Different stages in the square's urban space transitions reflect different generations' demands in their social life. Analysing spatial, functional and physical qualities of Baharestan Square clarifies that its special location near the first Iranian Parliament building (Senate), Sepahsalar Mosque and Negarestan Garden represent it as the first modern focal point in Iranian's political and social life.

\section{REFERENCES}

[1] Kheirabadi, M., Iranian Cities: Formation and Development, University of Texas Press: Austin, TX, 1991.

[2] Ahari, Zahara, \& Habibi, Mohsen, Baharestan Square; Experience of Modernism in Iranian Urban Space, Cultural Research Center: Tehran, 2015.

[3] Soltani, Zohreh, The transformation of public space: city squares as locations for power struggle - the case of Tehran (1934-2009). PhD Thesis, Middle East Technical University, 2011.

[4] Marefat, Mina, Building to Power: Architecture of Tehran 1921-1941, Massachusetts Institute of Technology: Cambridge, MA, 1988.

[5] Madanipour, Ali, Public and Private Spaces of the City, Routledge Press: New York, 2003.

[6] Habibi, M., From Shar to Shahr, Tehran University Press: Tehran, 2013.

[7] MohammadzadehMehr, Farrokh, Toopkhaneh Square, Moavenat-e Shahrsazi va Memari: Tehran, 2003.

[8] Madanipour, Ali, Tehran: The Making of a Metropolis, Wiley: New York, 1998.

[9] Graham, Robert, Iran: The Illusion of Power, Lowe and Brydone Printers: London, 1978.

[10] Motamedi, Mohsen, Historical Geography of Tehran, trans. author, Markaz-e Nashr-e Daneshgahi: Tehran, 2002.

[11] Savadkouhifar, Sasan, Tehran Squares in the Passage of Time, Behrad Press:Tehran, 1999.

[12] Gharib, F., City Squares, Architecture and Design of Open Spaces, University of Tehran: Tehran, 2009.

[13] Mehan, Asma, Public squares and their potential for social interactions: a case study of historical public squares in Tehran. International Journal of Architectural and Environmental Engineering (World Academy of Science, Engineering and Technology), 3(2), p. 547, 2016. 
[14] Diba, Darab, Iran and contemporary architecture. Mimar, 38, pp. 20-25, 1991.

[15] Mirgholami, Alireza, Iranian Modernity: Its Expression in the Daily life of Public Spaces in Tehran, The University of Melbourne: Melbourne, 2009.

[16] Amir Ahmadi, Hooshang \& Kianfar, Ali, The Transformation of Tehran from a Garrison Town to a Primate City: A Tale of Rapid Growth and Uneven Development, Center for Urban Policy Research: New Brunswick, NJ, 1993.

[17] Mazumdar, Sanjoy, Autocratic control and urban design: the case of Tehran, Iran. Journal of Urban Design (Routledge, Tylor \& Francis Group), 5(3), pp. 317-338, 2000. DOI: $10.1080 / 713683966$.

[18] Alemi, Mahvash, The 1891 map of Tehran: two cities, two cores, two cultures. Edited by Attilo Petruccioli. Environmental Design: Journal of the Islamic Environmental Design Research Centre (Rome: Carucci Editions), 1, pp. 74-84, 1985.

[19] Katouzian, Shahab, Tehran, capital city: 1786-1997. The re-invention of a metropolis. Edited by Attilo Petruccioli. Environmental Design: Journal of the Islamic Environmental Design Research Centre 1 (Rome: Dell'oca Editore), 1, pp. 34-45, 1996.

[20] Wilber, Donald N., Contemporary Iran, 1st ed., Frederick A. Praeger: New York, 1963.

[21] Bagheri, Nazgol, Modernizing the public space: gender identities, multiple modernities, and space politics in Tehran. PhD Thesis, University of Missouri-Kansas City, Kansas, Missouri, 2013.

[22] Bayat, Asef, Tehran: paradox city. New Left Review, 66, pp. 99-122, 2010.

[23] Costello, Vincent F., The morphology of Tehran: a preliminary study. Eastern Urban Form and Culture (Alexandrine Press), 24(4), pp. 201-216, 1998.

[24] Norouzi Talab, Hamid Reza, Tehran: Past\& Present; A Glance at the features of Life, Art and Architecture, Yassavoli Publications: Tehran, 2008.

[25] Shahri, Jafar, The Old Tehran, Moin Publication: Tehran, 1993.

[26] Mehryar, Mohammad, Pictorial Documents of Iranian Cities in the Qajar Period, Shahid Beheshti University: Tehran, 1999.

[27] Serena, Karla, Madam Karla Serena Dieries (in Persian), trans. Ali Asghar Saiedi, Zavvar Press: Tehran, 1983.

[28] Takmil Homayon, Naser, Cultural and Social History of Tehran (in Persian), Vol. 2, Cultural Research Center: Tehran, 2000.

[29] Nafisi, Saeid, Family Conversation about Old Tehran (in Persian), Vol. 10, Bongah Tarjome va Nashre Ketab: Tehran, 1975.

[30] Sepehr, Abdulhosein, Notes of Malek Al Movarekhin (in Persian), ed. Dr. Abdulhosein Navaiee, Zarrin: Tehran, 1989.

[31] Mostofi, Abdollah, Social History of Iran during Qajar era (in Persian), Zavvareh: Tehran, 1943.

[32] Pakdaman, Behrouz, A Review to Tehran's Architectural Styles (in Persian), Vol. 2, Roshangaran: Tehran, 1997.

[33] Tahami, Dariush, Old Photos of Tehran, Bank-e Ghalam: Tehran.

[34] Hourcade, Bernard, Tehran Capitale Bicentenaire, ed. Shahriar Adl and trans. Aboalhasan Sarvghad Moghaddam, Sazman Moshaver fanni va Mohandesi: Tehran, 1996.

[35] Bastani Raad, Hasan, Baharestan during the History (in Persian), Library, Museum and the Center for Senate Documents: Tehran, 2011. 